\title{
Managerial Networks and Exploration in a Professional Service Firm
}

Rogan, Michelle; Mors, Louise

\author{
Document Version \\ Accepted author manuscript \\ Published in: \\ Organization Studies \\ DOI: \\ $10.1177 / 0170840616663243$ \\ Publication date: \\ 2017 \\ License \\ Unspecified
}

Citation for published version (APA):

Rogan, M., \& Mors, L. (2017). Managerial Networks and Exploration in a Professional Service Firm.

Organization Studies, 38(2), 225-249. https://doi.org/10.1177/0170840616663243

Link to publication in CBS Research Portal

\section{General rights}

Copyright and moral rights for the publications made accessible in the public portal are retained by the authors and/or other copyright owners and it is a condition of accessing publications that users recognise and abide by the legal requirements associated with these rights.

\section{Take down policy}

If you believe that this document breaches copyright please contact us (research.lib@cbs.dk) providing details, and we will remove access to the work immediately and investigate your claim.

Download date: 26. Apr. 2023 


\section{Managerial Networks and Exploration in a Professional Service Firm}

\section{Michelle Rogan and Marie Louise Mors}

Journal article (Post print version)

CITE: Managerial Networks and Exploration in a Professional Service Firm. / Rogan, Michelle;

Mors, Louise. In: Organization Studies, Vol. 38, No. 2, 02.2017, p. 225-249.

DOI: 10.1177/0170840616663243

Uploaded to Research@CBS: June 2017 


\title{
Managerial networks and exploration in a professional service firm*
}

\author{
Michelle Rogan \\ INSEAD \\ Boulevard de Constance \\ 77305 Fontainebleau Cedex \\ France \\ michelle.rogan@insead.edu \\ Tel. +33 (0)1 60724811 \\ Marie Louise Mors \\ Copenhagen Business School \\ Kilevej 14A \\ DK-2000 Frederiksberg \\ Denmark \\ lm.smg@cbs.dk \\ Tel. +4538154262
}

May 2016

\begin{abstract}
Keywords
Exploration, innovation, firm performance, networks, network content, network structure, new business development, new knowledge development, professional service firms, consulting firms, corporate entrepreneurship
\end{abstract}

\footnotetext{
${ }^{*}$ We thank Gautam Ahuja, Kathy Eisenhardt, Stephen Floyd, Gerry George, Ben Hallen, Morten Hansen, Herminia Ibarra, Susan Lynch, Bill McEvily, Ray Reagans, Giuseppe Soda, Jesper Sørensen, Olav Sorenson, Marco Tortoriello, Margarethe Wiersema and Akbar Zaheer for their helpful comments on earlier drafts. We are also grateful to Ha Hoang for helpful editorial guidance and to the anonymous reviewers for their comments. This paper would not have been possible without the insightful work of our colleague and friend, Bjørn Løvås (1967-2005). This paper is written in his memory.
} 


\title{
Managerial networks and exploration in a professional service firm
}

\begin{abstract}
A firm's growth and survival depends on the ability of its managers to explore for new business and knowledge; yet, exploration is challenging for most large, established firms. Extending prior research into networks and exploration, we propose that a key characteristic of managers' external networks - the extent to which their networks include relationships built using predominately individual rather than firm resources - is positively related to managers' abilities to explore for new business and knowledge in large firms. We propose that networks with more individual ties provide more diverse knowledge, enable greater autonomy, and ease access to resources from contacts; hence facilitating exploration. Analysis of an original dataset of external networks of 77 senior managers in a large global consulting firm provides support for our arguments. We find that individual ties are positively related to exploration and furthermore, that the positive (negative) relationship between sparse (dense) networks and exploration increases with the number of individual ties in managers' networks.
\end{abstract}

\section{Keywords}

Exploration, innovation, firm performance, networks, network content, network structure, new business development, new knowledge development, professional service firms, consulting firms, corporate entrepreneurship 


\section{Introduction}

How do the external networks of managers affect exploration in large professional services firms? Exploration for new opportunities is a central challenge for large, established firms (March, 1991). The specialized roles, routines and procedures of established firms tend to limit the exploration behavior of individuals working in these firms (Dobrev \& Barnett, 2005; Sørensen, 2007). In large professional services firms, the shift away from exploration towards exploitation means that managers tend to rely more on proprietary knowledge and firm expertise rather than individual expertise (Brivot, 2011; Fosstenløkken, Løwendahl \& Revang, 2003; Freeman and Sandwell, 2008). Furthermore, failure to identify new knowledge and new business can lead to lower performance and ultimately threaten the survival of the firm (Christensen \& Raynor, 2003; Penrose, 1959).

Scholars adopting a network perspective have argued that in established firms, managers' external networks of relationships play an important role in the firm's ability to explore for new business and new knowledge (Ahuja, 2000; Gulati, Nohria \& Zaheer, 2000). Previous research has established that dense networks - networks in which a manager's contacts are also directly connected to one another - are associated with less new information flowing to the manager (e.g., Burt 1992; Reagans \& Zuckerman, 2001) and narrower search for ideas (Hansen, Mors \& Løvås, 2005). In contrast, sparse networks provide diverse information and support broader search as required for exploration (Lazer \& Friedman, 2007). Recent work on professional services firms has also addressed this challenge and underscored the important role that managers' networks play in facilitating exploration (Fu, 2015; Glückler \& Armbrüster, 2003; Karantinou \& Hogg, 2009; Robertson, Scarbrough \& Swan, 2003). For example, it has been argued that new business 
opportunities and new knowledge often arise when managers engage with clients in solving specific problems or challenges (Fosstenløkken et al., 2003; Nikolova, 2012).

Although the network literature and the professional services literature concur regarding the importance of external networks for exploration, the types of networks that support exploration remain unclear. As noted above, network scholars argue that sparse networks provide diverse information and the autonomy needed for exploration (e.g., Burt, 1992). In contrast, findings of studies of professional service firms suggest that sparse networks are insufficient for exploration (Nikolova, 2012). In these firms, services are co-produced between clients and the professional service firm - i.e., clients must be involved in the creation and delivery of the service they receive (Fosstenløkken et al., 2003; Løwendahl, 1997; 2005; Reihlen \& Werr, 2012; Skjølsvik et al., 2007). Exploration therefore requires the involvement of clients, yet this also creates risk for these clients in that they need to invest their time and resources in these relationships (Gardner, Anand \& Morris, 2008; Glückler \& Armbrüster, 2003). Such investments are not well managed in sparse networks, especially under conditions of uncertainty (Kijkuit \& van den Ende, 2010). This presents a puzzle - if the sparse network structures associated with exploration in other contexts are insufficient for exploration in professional services, what kinds of networks support exploration in professional service firms?

To address this puzzle, we consider an additional characteristic of managers' external networks - the extent to which their networks include relationships built using predominately individual rather than firm resources, which we refer to as individual ties. Research shows that professional service firms traditionally have relied on personalized interactions with clients when exploring for novel knowledge, ideas, and business opportunities (Karantinou \& Hogg, 2009; Taminiau \& Berghman, 2010). Yet, as the firms grow, the establishment of formal structures and 
procedures reduces the reliance on personalized interactions with clients, and firms focus on the reuse of existing knowledge rather than the exploration for new knowledge (Hansen, Nohria \& Tierney, 1999; Werr \& Stjernberg, 2003). We propose that the move away from informal, individual relationships to formal, firm relationships, as professional service firms grow and age, is part of the reason that large, established firms struggle with exploration.

Our theorizing begins with the observation that building and maintaining relationships requires the investment of resources (Burt, 2000; Vissa \& Bhagavatula, 2012). These resources could include physical assets, financial capital, knowledge, or social capital. Regardless of the type of resource, an important distinction exists (Lin, 2001; Løwendahl, 1997; 2005; Sorenson \& Rogan, 2014). Some resources rest with individual managers and are accumulated through prior experience or through schools, events or families, and these are available regardless of their current employment. Yet, other resources rest with the firm, and the manager has access to these only via membership in the firm. Thus, when building and maintaining external networks, a manager has a choice about whether to invest more of the firm's resources or more of his or her individual resources. We propose that relationships built and maintained using predominately individual resources are more likely to connect the firm to diverse information, provide greater autonomy to managers, and ease access to resources held by contacts. Thus, managers with more individual ties in their networks will be better at exploration.

Arguments for the role that individual ties play in exploration in professional service firms also help resolve conflicting findings between the network literature and the professional service firms' literature regarding the effect of network structure on exploration. Building on arguments from network theory, we propose that although network structure provides the potential for different types of information and resource flows, the actual content of the network varies. 
Network content refers to "...the qualitative nature of the relationships" (Rodan \& Galunic, 2004: 543) and the set of resources that flows across relationships (Lin, 2001; Podolny, 2001; Tichy, Tushman, \& Fombrun, 1979; see Borgatti \& Foster (2003) and Hoang \& Antoncic (2003) for reviews). Moreover, recent studies have demonstrated that the effect of network structure can be contingent upon network content (Chua, Ingram, \& Morris, 2008; Kijkuit \& van den Ende, 2010; Podolny \& Baron, 1997; Rodan \& Galunic, 2004; Tasselli, 2015). Thus, the value of sparse networks (i.e. network structure) for exploration in large professional service firms may be contingent upon the presence of individual ties (i.e. network content).

We test our arguments using original data on the professional networks for a sample of 77 managing partners (i.e. senior managers) in a large, global consulting firm. The exploration outcomes we observe are senior managers' abilities to grow the firm via new business and new knowledge development. The specific questions we address are: for managers in large professional service firms, how does the investment of individual resources in their professional relationships (i.e. individual ties) relate to their exploration behavior? And, is the effect of network structure on exploration contingent upon the number of individual ties in the manager's network? We find support for our main argument that individual ties are positively related to managers' exploration behavior. Furthermore we find evidence of an interaction between network structure and individual ties where the effect of sparse (dense) networks on exploration increases (decreases) with the number of individual ties in the network.

\section{Theory}

\section{Exploration in professional service firms}

In professional services, exploration for new business opportunities and new knowledge is essential to the long-term performance and survival of firms (Anand, Gardner \& Morris 2007; 
Gardner et al, 2008; Reihlen \& Werr, 2015). Yet, exploration is a challenge for most firms, and in particular for large established firms that focus on the refinement of existing knowledge and skills and emphasize knowledge reuse (Hansen et al., 1999). This contrasts to the emphasis on variation and broad search required for exploration (Katila \& Ahuja, 2002; March, 1991). Prior studies adopting a network perspective have long established that sparsely connected networks are better for exploration due to the greater novelty of information assumed to flow through them (Burt, 1992; Granovetter, 1973; Lazer and Friedman, 2007). Furthermore, because the new business and new knowledge associated with exploration often arise from novel combinations of skills and resources that are not currently recognized as important to the firm, by providing greater autonomy, sparse networks help managers explore in these areas (Burgelman, 1983, 1991; Criscuolo, Salter \& Ter Wal, 2013; McGrath, 2001).

While theories of sparse networks explain the value of such networks for exploration in general, they provide less explanatory power in studies of professional service firms. Part of the shortcoming stems from the strong emphasis on network structure and lack of attention to the content of the network. This is problematic because arguments for the effect of network structure on performance outcomes have relied on explanatory mechanisms that assume the content of networks. For example, researchers have argued that the positive relationship between sparse networks and outcomes such as innovation or exploration comes from diverse content flowing in the network. Yet, in most studies, content has not actually been measured (e.g., Reagans \& Zuckerman, 2001). Furthermore, studies that have observed network content suggest that it has an effect above and beyond that of structure on a manager's innovation performance (Kijkuit \& van den Ende, 2010, Rodan \& Galunic, 2004; Tortoriello \& Krackhardt, 2010) and team performance (Soda \& Zaheer, 2008) and that the effect of structure varies with network content. 
For example, Podolny and Baron (1997) find that the performance benefits of the network structure vary with network content. In a recent study of healthcare professionals, Tasselli (2015) shows that individual professional's characteristics interacted with network structure to affect knowledge transfer patterns. In other words, sparse networks may offer a greater potential for diverse information, but it is the bandwidth of each relationship, i.e. its ability to transmit content, that determines if information actually flows through networks (Aral \& van Alstyne, 2011).

Network content as resources invested

Investigation into the role of individual relationships as a form of network content is an important step towards the development of a more complete theory of networks and exploration. While recent studies have begun to explore what flows in network ties, we still know little about the investment of resources into building and maintaining such ties. In particular, organization scholars have focused on the nature of the resources flowing to an organization member from the contacts in their network, but have not examined the resources that the focal organization member invests into maintaining the relationships (e.g., Rodan \& Galunic, 2004; Tortoriello \& Krackhardt, 2010). Building on Borgatti and Halgin's (2011: 3) definition of network content as “...flows ...[that] pass between nodes as they interact, such as ideas or goods," we argue that a complete theory must consider both the flows of resources individuals seek in their network ties and the resources they invest in building these. In this study, we extend prior research by examining the resources managers choose to invest in their networks and the implications of this choice for performance.

In professional service firms, managers regularly build and maintain professional relationships outside the firm to accomplish their work, for example ties to existing or 
prospective customers, business associations, industry and knowledge experts, and acquaintances with shared affiliations. For all professional relationships, access to a contact's resources (e.g. advice, support, information) requires the investment of reciprocal resources by the manager in the relationship (Emerson, 1962; Gouldner, 1960). Thus, the formation and maintenance of the relationship requires the investment of resources whether it be the investment of specialized knowledge or expertise, financial capital, physical assets or social capital (Burt, 2000; Karantinou \& Hogg, 2009).

As members of established firms, managers have different sets of resources available to them that can be used to build and maintain professional relationships (Løwendahl, 1997; 2005). Some of these are available to them regardless of their current group or firm membership(s). As described by Løwendahl (2005: 89), individuals carry with them competences that could include their professional knowledge, client and industry knowledge, project management experience or communication skills. For example, a manager may draw upon her personal knowledge and experience accumulated over time in a particular industry or technology to build relationships with her professional contacts. Other resources are available to managers because they are tied to the manager's formal position in the firm (Lin, 2001; Løwendahl, 1997). Løwendahl (2005: 8990) describes these as "knowledge, both in the form of data bases and other types of information about customers, competitors, etc.", "routines, standard operating procedures, etc." and "collective competences" which "may exist independently of individuals, such as when routines are manifested in quality control manuals and hence can be transferred to new employees without the participation of senior colleagues." For example, a manager using firm resources may invite a contact to a firm facility, such as the firm's innovation lab, to demonstrate the firm's capability and share the firm's expertise. Finally, the investment of resources may include 
both individual and firm resources, and a network may be comprised of relationships that are firm relationships, individual relationships or a combination of both. The important distinction for our arguments is that some of these relationships are predominately individual ties, and that managers with networks that include these individual ties should be better at exploration.

This distinction is most relevant in large firms. In small firms, the firm resources available to managers are likely to be limited and at the extreme, individual and firm resources may be one and the same, as in entrepreneurial start-ups (Sorenson \& Rogan, 2014). In large firms, a clearer distinction between individual and firm resources exists. According to Lin (2001), in large firms, resources that organization members can access as a result of their formal job positions are much more useful to them than the resources they have access to as a result of their personal contacts. This is because the resources that are available to them via their formal position carry with them "the power, wealth and reputation of the organization itself" (2001: 45). Moreover, the firm's resources represent a readily available stock of resources that can be drawn upon, and often at a lower cost than using individual resources. This perspective is similar to that of Hansen and colleagues (1999) when they describe knowledge strategies where consultants rely on resources already available to them in the firm. In contrast, developing a comparable set of individual resources requires investment of time and effort on the part of the individual.

As professional services firms grow larger, senior managers take responsibility for large client projects. Their roles shift from those involving personalized client interactions to roles involving the management of large global projects characterized by standardized routines. This shift entails an increasing dependence on formal, firm resources. From the perspective of the firm, a manager's reliance on firm resources is attractive because it reduces the firm's vulnerability to the loss of the manager's relationships if the manager should leave the firm. Yet, 
as we argue below, the manager's reliance on firm resources also has implications for the identification of new business and new knowledge for firms, and as a result, over reliance on firm resources can be detrimental to exploration. ${ }^{1}$

\section{Investing individual resources in professional relationships and exploration}

Investing individual resources in professional relationships is critical to a manager's exploration behavior for at least three reasons. First, individual ties have the potential to provide more diverse information than firm ties. The identification of new opportunities for the firm requires both variation and broad search (Katila \& Ahuja, 2002; March, 1991). In a manager's network, this means that relationships that provide access to more diverse information are better for exploration. The individual resources available for managers to invest in their relationships are typically accumulated via previous experiences and expertise in education, previous jobs, or social ties such as kinship or friendship (Løwendahl 1997; 2005). Relying primarily on individual resources as opposed to firm resources, a manager can build ties with contacts that may not be interested in or related to the firm's current resources. That is, a manager could invest unique knowledge developed outside of the firm's formal training program to form ties to target a different set of contacts than those targeted by managers relying on knowledge gained in formal firm training. Consider another example; if a firm's current clients are mainly large oil and gas firms, the ties that are formed using firm resources will mostly be to contacts working in those industries. Now imagine that one manager uses individual resources rather than firm resources to build some ties. Those contacts that are developed using individual resources, are not necessarily in the industries and markets currently served by the firm. They could include a

\footnotetext{
${ }^{1}$ It is possible that a relationship formed via the investment of firm resources could develop into an individual relationship at a later stage if the manager begins to invest more individual resources in the relationship rather than firm resources. This dynamic perspective on the investment of relationships is a complication that is beyond the scope of the current investigation but that surely merits future examination.
} 
university classmate who works in robotics, or an acquaintance made while traveling who works in furniture design. The manager investing individual resources will consequently be exposed to information about the latest thinking in robotics and design, and not only to the knowledge about trends in oil and gas to which his other colleagues will be exposed. Managers with networks comprised of more individual ties are exposed to more diverse information relative to their colleagues with networks consisting primarily of firm ties. Hence, in aggregate, networks created by primarily investing individual resources bring diverse information. Therefore, we expect that such networks are positively associated with exploration.

Second, individual ties enable greater autonomy. Because growth from new business and new knowledge often arises from novel combinations of skills that are not currently recognized as important to the firm, a manager's ability to explore depends on having autonomy. (Burgelman, 1983, 1991; Criscuolo, Salter \& Ter Wal, 2013; McGrath, 2001; Robertson et al., 2003). According to prior theory, the autonomy of a manager is a function of the manager's dependence on the firm. As White (1974: 369) argues, the behavior of individuals is constrained by both "the kinds of resources controlled by the organization and the utilization of such resources." Similarly, Litwak (1961) documented how some organizations limit the autonomy of professionals by restricting them to using resources from within the organization. In contrast, because the continuity of individual ties does not depend on the manager's membership in the firm and only depends on continued access to individual resources, the manager can maintain these ties even if she leaves the firm (Broschak, 2004; Groysberg \& Lee, 2009). As a result, we expect that managers that invest primarily individual resources in their professional relationships are more autonomous and should be able to pursue activities that are new to the firm. 
Third, individual ties are likely to provide easier access to resources from contacts in the network. In social exchange, the willingness of one contact to provide resources to another depends on their expectations of reciprocity in the relationship. While a norm of reciprocity governs all social behavior, including relationships between firms, the strength of reciprocity is greater in relationships imbued with a personal dimension (Blau, 1964). In individual ties, contacts trust that the manager will reciprocate in the future by helping the contact at the time of need, and so the contact is more willing to provide access to resources without concern for immediate reciprocation (Bouty, 2000). This greater ease of access to resources and knowledge via personal ties is illustrated by Mariotti and Delbridge (2012) in their qualitative study of the European motorsport industry. They showed that personal ties of employees provide an important means of forging new interorganizational ties, especially when searching for new knowledge or new partners because "personal ties reduce uncertainty about potential partners and provide quicker and easier access into resources and knowledge" (Mariotti \& Delbridge, 2012: 518-519). Similarly, in our setting, managers with individual ties should have more reliable access to the resources their contacts provide.

Hence, we expect that having more individual ties in managers' professional networks will aid exploration. Formally,

Hypothesis 1. The count of individual ties in a manager's network is positively related to managerial exploration.

As noted in the introduction, a criticism of prior research on networks has been its predominant focus on network structure with the content of ties being inferred from the structure. In studies of network structure, a main empirical focus has been network density, or the extent to which a manager's contacts are also directly connected to one another (e.g., Reagans \& McEvily, 
2003). Previous research has established that dense networks are associated with less new information flowing to an individual (e.g., Burt 1992; Reagans \& Zuckerman, 2001) and narrower search (Hansen, 1999; Hansen et al., 2005). The cohesion and norm enforcement associated with dense networks can constrain behavior. Managers are less likely to pursue risky, uncertain projects and more likely to work on projects related to the main business of the firm. In contrast, sparse networks, i.e. networks in which the manager's contacts are not connected to one another, are associated with more novel information and lower constraint. Access to novel information is positively related to performance outcomes such as new business identification (Moran, 2005), new knowledge creation (Nahapiet \& Ghoshal, 1998; Obstfeld, 2005), and rates of innovation (Rodan \& Galunic, 2004; Tortoriello \& Krackhardt, 2010). Thus, in network theory, dense networks are predicted to be negatively related to the search behavior integral to exploration.

In contrast, scholars studying professional service firms have argued that sparse networks are not necessarily positively associated with exploration and may even have a negative association (e.g., Fosstenløkken et al., 2003; Glückler \& Armbrüster, 2003; Nikolova, 2012). The reason for these contradictory arguments could be because although the structure provides the potential to access diverse knowledge, the characteristics of the ties themselves (i.e. content) affect whether that potential is realized. Network sparseness or density affects the potential for accessing diverse information, knowledge and resources, but whether network structure actually aids exploration depends in part on the presence of individual ties in managers' networks. As noted by Glückler and Armbrüster (2003: 270); under conditions of uncertainty, "personal experience that evolves from interaction between clients and consultants becomes most important in reducing uncertainty..." Relative to exploitation, exploration is characterized by 
greater uncertainty (March, 1991). Furthermore, as noted above, exploration in professional services requires involvement of the client (Fosstenløkken et al., 2003; Løwendahl, 1997; 2005).

Relative to formal, firm ties, individual ties have a greater potential for generating the trust and reciprocity required by external contacts such as clients to engage in novel, uncertain opportunities with the firm. Hence, sparse networks may have a positive association with exploration, but only when these networks include individual ties. This prediction is in line with findings by Rodan and Galunic (2004). In their study of managers' innovation performance in a telecommunications company, the positive influence of the heterogeneity of knowledge in a manager's network on performance is greatest in sparse networks. They argue that although sparse networks provide opportunities for brokerage of knowledge, it is the actual knowledge that a manager has access to, i.e. the content of the network, which determines the effect of network structure on performance. Similarly, in the context of our study, we expect that manager's sparse networks increase the potential for identifying new business and knowledge for the firm, but the content of the ties - i.e., whether the network includes individual ties - affects whether these opportunities can be realized by the manager. Formally,

Hypothesis 2. The positive (negative) effect of network sparseness (density) on managerial exploration increases with the count of individual ties in the manager's network.

\section{Methods}

\section{Empirical setting}

We tested our predictions using sample data collected on the external professional networks of partners in a large, established global management consulting firm (hereafter referred to as 'the firm'). At the time of data collection, the firm had annual sales of more than US\$500 million, employed more than 10,000 professionals worldwide, and operated in more than 40 countries. 
The firm was engaged in a wide range of management consulting activities. Like most major consulting firms, it had a partnership structure including analysts, consultants, project managers, senior project managers, associate partners, and senior partners. The firm had been profitable for a number of years, and during the ten years prior to data collection it had continued to grow in terms of sales, profits, and people. The firm was primarily organized in global industry groups, with functional specialty and geography as two secondary dimensions. As in many professional services firms, the partners were the main performance units. In this study, we use the individual partner as the unit of analysis.

Collecting data from the firm required a significant effort over more than two years involving several people. Before commencing the data collection a significant amount of time was spent negotiating access to the firm as the data were sensitive and required us to survey senior partners across the firm. In the first phase of the study, in-depth interviews were conducted with 32 senior partners across five Western European countries. The purpose of these interviews was to explore the role of professional networks for the performance of these partners and to provide input to the design of the survey used in the second phase of data collection. We further utilized the interviews to help inform us about the workings of the firm. The interviews provided reassurance regarding our choice of empirical setting for investigating the role of networks on exploration. The interviews confirmed the partners concern with exploring for new knowledge and business. Explained one partner, "You get there [at the client site] and you want to develop new opportunities with that client. [Also] you need to look for other clients and this is something that everybody clearly has on their minds." Similarly another partner commented, "Unless you are rejuvenating yourself...unless you're bringing in new ideas, your business doesn't become sustainable." The partners also expressed that they actively invested in building 
professional networks but that they differed in the extent to which they relied on individual v. firm ties. As an example illustrating firm ties, one partner explained: "I rely more on my team members to carry some of that client relationship, and less on [me] personally. I'm very happy to let other people stand in front.... It would probably be very easy to pull me out of here and put me somewhere else if they had to." In contrast as an example of individual ties, another partner commented: “...It's not about putting out very beautiful things up front [like the firm's brand]. It's about putting yourself up front with this [in the] background.... The firm should be behind you and not the contrary." Thus, although we rely on the survey data collection described below for the tests of our hypotheses, the preliminary qualitative data gathered in these interviews provided useful insights into the way that the partners built their professional networks which informed our survey design.

\section{Survey data collection}

In the second phase of the study, quantitative data were collected via two surveys over three stages. First, a pilot test of the survey was conducted to eliminate all potential biases arising from the sequencing or wording of questionnaire items. Ten partners were selected to pilot the survey, six in the US and four in Europe. Feedback from the pilot study subjects indicated that an inperson interview format would generate the highest response rate and provide more accurate and complete data. Therefore, we adapted the survey for use in a face-to-face interview format. In the second stage of quantitative data collection, 147 partners from offices located in New York, Chicago, San Francisco, London, Paris, Milan, Madrid, Frankfurt, Tokyo, and Sydney were randomly selected for participation in the survey. A total of 133 survey interviews were scheduled. Of these a total of 102 survey interviews were completed. ${ }^{2}$

\footnotetext{
${ }^{2}$ To rule out systematic bias between the partners sampled and those interviewed, we tested for differences in the mean values of the main organizational units of the firm (Levene, 1960). There were no significant differences
} 
The design of the survey adhered to the standard methodology for egocentric network survey designs (e.g., Burt 1984, 1992). ${ }^{3}$ The survey was organized in four main sections: (i) demographic data (ii) identification and description of contact networks of each partner, i.e., name generator questions (iii) characteristics of each of the contacts in the individual partner's network, i.e., name interpreter questions. The name generator questions used to build the contact network were adapted to the firm and were based on whom the partners relied to identify new business opportunities, to negotiate and close deals, to provide new knowledge and expertise, to develop their skills, to provide operational support, and sponsor their projects. The name generator questions are given in Appendix A. ${ }^{4}$ A partner could identify a maximum of 24 different network contacts in their total network, including internal ties (i.e. co-workers) or external ties (i.e. contacts not employed by the firm). To construct the structural measures for each of the partner's networks, we asked each partner to indicate the existence of relationships among the contacts they named. Each network survey was administered face-to-face by one of the interviewers during a 90-minute meeting with each individual partner.

In the third stage of data collection via a separate survey, the lead investigator interviewed the supervising partners of the study subjects to gather performance data. Due to legality and confidentiality issues regarding annual review documents at the firm, we were unable to gather this information directly from human resources. Therefore, we used an approach to performance data collection consistent with related research on the performance of individual

across industry group and functional specialization. Geographic location did reveal slight differences. However these differences were a function of the availability of the interviewers in different geographic locations, not the partner's propensity to participate.

${ }^{3}$ An egocentric survey design was the best approach for collecting network data in this setting. The firm had more than 10,000 employees, and given that we include external network contacts, a list of potential contacts would have been essentially boundless. Moreover, using an egocentric survey instrument is a commonly used and valid method when mapping individual actor networks (cf. Burt, 2007; Everett and Borgatti, 2005; Marsden, 2002).

${ }^{4}$ By definition, the operational support network could only include internal contacts, and therefore, these ties were not included in the analyses. 
managers in consulting firms, in which confidentiality issues did not allow access to actual performance data (e.g. Cross \& Cummings, 2004). The supervising partners agreed to provide an assessment of each partner's performance. These performance data were collected via 30-minute phone interviews with the supervising partners shortly after the official annual reviews of the partners were completed. The evaluation survey was developed and piloted with the managing partners sponsoring the project to ensure that the questions were closely related to those in the actual internal annual review. In total, performance data on 79 of the 102 partners surveyed were collected. Of these, two reported no external ties in their networks and thus they were not included in the analysis, yielding a final sample size of 77.

\section{Dependent variables}

Managerial exploration. We measured exploration as a manager's capability for new business development and new knowledge development, two key dimensions to the annual performance review at the firm and a salient measure of exploration behavior in this particular empirical context (Anand et al., 2007; Maister, 1993). Each partner was rated by their supervisor on a fivepoint Likert scale: from one: 'Much better at implementing existing business' to five: 'Much better at new business development' and from one: 'Much better at leveraging existing knowledge and expertise' and 'Much better at developing new knowledge and expertise.' 'New' refers to activity in which the firm has not yet engaged, as opposed to an expansion or renewal based on existing practices with existing clients. Thus, new business development includes the development of new business activities, with new or existing clients, and new knowledge development includes the development of knowledge and expertise not previously known to the firm. We created the managerial exploration measure by taking the square root of the product of the new business development and new knowledge development following the approach of 
Rodan and Galunic (2004)..$^{5}$ Measured this way; a partner's score is most accurately understood as a single item indicating a manager's exploration behavior.

\section{Independent Variables}

Individual ties. The extent to which the partner invested individual resources in relationships was measured by asking the partners which resources they used to build and maintain their relationship with each of the contacts they listed in the survey. On the written questionnaire item, the partners were reminded that they invested resources to build and maintain their network ties, and that some of these resources were individual (e.g. personal knowledge, expertise, reputation, or friendship) and independent of their formal role in the firm and some were available to them through their membership and formal position in the firm (e.g. the firm's knowledge, reputation, or delivery capacity). The partners were asked to indicate on a five-point Likert scale the resources they used to build and maintain each relationship from mostly formal, firm resources to mostly informal, individual resources. A score of one or two indicated that the resources that were used to build and maintain the relationship were predominately firm resources. A score of four or five indicated that the partner mainly invested individual resources. A score of three indicated that the partner used a combination of resources. We coded those relationships that were rated a four or five as individual ties and aggregated the tie level data to the partner level, and included a count of individual ties for each of the partner's networks in the models. ${ }^{6}$

Network density. Network density is the extent to which a partner's contacts interact with one another. Each respondent rated the potential relationships among the contacts in the network

\footnotetext{
${ }^{5}$ We also estimated the models for each dimension of exploration separately and using the mean of new business development and new knowledge development as the dependent variable. The pattern of results was consistent with those reported here.

${ }^{6} \mathrm{We}$ also estimated the models including the count of ties where the partners primarily invested firm resources (rated as 1 or 2) and mix of resources (rated as 3) in the models. The results for the effect of the count of ties investing individual resources remain the same. However, for parsimony, we have chosen to include only the number of ties where the partners invested primarily individual resources in the reported models. We do include a control for external network size, which accounts for the ties that are built primarily with firm or mixed resources.
} 
as "distant", "neither distant nor close" or "close". A rating of "close" indicated that a tie existed between those two contacts. Those ties were used to construct a network density measure according to the method proposed by Borgatti, Everett and Freeman (2002) for ego-centric network data, which is as follows:

$$
\text { Network density }=\text { ties } /\left[\left(\operatorname{size}^{*}(\text { size-1) }) / 2\right]\right.
$$

Ties are the number of ties existing among the contacts in the partner's network. Size is the total number of contacts in the partner's network. A high score on network density indicates that the partner's contacts are interconnected, whereas a low score indicates that the partner's network is sparse, i.e. the contacts are not connected to one another.

Interaction effects. We created a measure of the interaction of individual ties with network density. To avoid issues of multicollinearity, we centered the constituent variables before creating the interaction effect in accordance with the procedures suggested by Aiken and West (1991).

\section{Control variables}

Partner characteristics. We included standard human capital controls that could affect the relationship between our explanatory variables and dependent variable, including age, gender, and education. Time to partner, or the number of years a manager was employed by the firm before promotion to partner, was included to capture the socialization of managers into the firm's routines, which could bias a manager against new business or knowledge creation. We included a set of indicator variables for the skill area of the partner: strategy, change management, process, and technology. We also include the average growth rate in the partner's industry over the five years prior to the study year gathered from Value Line to control for industry driven differences in managerial exploration, as managers in faster growing industries may be perceived as being 
more explorative. ${ }^{7}$ We included a measure of each partner's revenue generation capability gathered during the interviews with the supervising partners (1 to 5 point Likert scale with 5 indicating highest level of revenue generation capability) as a control for underlying quality differences across partners. Finally, the partners in the sample were in the same level in the firm's hierarchy, thus we can rule out differences that may exist in use of firm versus individual resources due to differences in formal role.

Network characteristics. We include three external network variables as controls average tie strength, network size, and network knowledge heterogeneity. Stronger ties are more likely to provide more redundant information than weak ties (Capaldo, 2007; Hansen, 1999; Uzzi, 1999). Hence, strong ties could negatively impact a partner's ability to develop new business and knowledge. Consistent with prior studies (Marsden \& Campbell, 1984; Tsai \& Ghoshal, 1998) we measure tie strength as the average closeness to each contact measured on a five-point Likert scale from one indicating "distant" to five indicating "especially close." ${ }^{8}$ We also included a control for the size of each partner's network to control for the possibility that partners' with larger networks would be exposed to more information and thus better at new business and new knowledge development. Prior studies of network content (Rodan \& Galunic, 2004) show that the heterogeneity of knowledge of a manager's network affects innovation performance. Therefore we include a control for knowledge heterogeneity measured as the count of industries represented in each partner's network. Although the focus of the study is on the effect of external networks on exploration, it is possible that internal networks affect the

\footnotetext{
${ }^{7}$ The source for these data is from the Value Line Database. The data were generously made available to us by Professor Aswath Damadoran at NYU (http://pages.stern.nyu.edu/ adamodar/).

${ }^{8}$ While frequency is also used to measure tie strength (e.g., Granovetter, 1973), closeness is a more accurate measure as two people may interact frequently but the tie may not be particularly strong (Marsden and Campbell, 1984). One survey was missing data regarding the closeness of the partner's contacts. We replaced the missing data with the sample mean. We also estimated the models omitting this observation and the results were consistent with those reported here.
} 
relationship between individual relationships in the external network and exploration (Mom et al., 2015), so we also control for the size and density of the internal networks.

Analysis

To test the hypotheses, we estimated the models using ordered logistic regression. The dependent variable, managerial exploration, has 11 ordered outcomes. Ordered logistic regression has two clear advantages over an ordinary least squares model. It does not require the assumption of constant intervals between categories, and it does not generate predicted values outside the range of possible values for the dependent variable (Kennedy, 2003; Long, 1997). However, we also confirmed that estimating the models using OLS produces consistent results. All models were generated using STATA's ologit command with robust standard errors clustered by the 21 raters (i.e. the supervising partners providing the performance data).

\section{Results}

Descriptive data and pair wise correlations are reported in Table $1 .{ }^{9}$ On average partners had five ties in their external networks. The mean count of individual ties was 1.43 ties with a standard deviation of 1.56 ties and range of 0 to 5 ties indicating significant variation across partners' use of resources. The mean network density was 0.20 with a standard deviation of 0.25 . On average partners build more ties using firm resources than individual resources. Both a paired T-test and a Wilcoxon signed-rank test indicate that the count of firm ties (mean=2.04) was significantly greater at $\mathrm{p}<0.05$ than the count of individual ties (mean=1.43) in partners' networks.

Insert Tables 1 and 2 about here

\footnotetext{
${ }^{9}$ Given potential multicollinearity between average closeness and the count of individual ties and network size and count of individual ties, we calculated the variance inflation factors for all models. All values were well below the recommended threshold of 10. In addition, we also ran the analysis including the orthogonalized components of average closeness and network size. The results for the explanatory variables remain the same as the results reported here.
} 
Models 1 to 3 in Table 2 show the results of the tests of the hypotheses. Model 4 is a reduced form model with the explanatory variables and the significant control variables only. In Model 2, the coefficient for individual ties is significant at the $1 \%$ level indicating that having individual ties in the network is positively related to managerial exploration as predicted in Hypothesis 1. Although we did not hypothesize a direction for the main effect of network density, our results show that the effect of network density on exploration is negative but not significant, consistent with prior studies that did not find a significant effect of density on innovation and exploration in professional service firms.

The interpretation of coefficients in logistic regression models requires estimation of the marginal effects of the independent variables across the range of values (Wiersema \& Bowen, 2009). Unlike OLS the effect of a given variable on the outcome is not a simple linear relationship, and the size and significance of the effect can vary at different values of the variable. Therefore, to interpret the relationship between individual ties and exploration, we followed the procedures recommended by Wiersema and Bowen (2009) and calculated the marginal effects of individual ties on exploration at the $25^{\text {th }}$ and $75^{\text {th }}$ percentiles holding all other variables at their means, as reported in Table 3. The marginal effect on exploration is positive and significant across the range of values for individual ties, supporting Hypothesis 1 . The magnitude of the effect is considerable. For example, the marginal effect of individual ties on being in the $75^{\text {th }}$ percentile of exploration increases by $26 \%$ with an increase from one to two individual ties in a partner's network. Thus, the results show strong support for Hypothesis 1, that the count of individual ties in the network is positively related to exploration.

Insert Table 3 and Figure 1 about here 
Hypotheses 2 predicting the interaction effect of individual ties and network density on exploration is tested in Model 3 of Table 2. The coefficient is negative as predicted, but not statistically significant. However, in nonlinear models, an interaction term's coefficient and standard error are not particularly informative because the effect of the interaction terms depends on the interaction's coefficients and the coefficients of the two effects and on the values of all other covariates (Ai \& Norton, 2003). Thus, the sign and significance of an interaction term are not indicative of the actual direction or significance of the effect (Greene, 2010; Hoetker, 2007).

To interpret the interaction effect predicted in Hypothesis 2, we calculated the marginal effect of individual ties as network density varies from 0 to 1 . As shown in Table 4 and Figure 2, despite the insignificant coefficient in Model 3 in Table 2, inspection of the marginal effects indicates that network density does significantly decrease the likelihood of being in the $75^{\text {th }}$ percentile for exploration. Yet, the density effect is significant only for a portion of the ranges of density and individual ties. As shown in Table 4, if the network includes no individual ties when network density is greater than 0.20 , its effect on exploration is not significant. However, if the network includes one individual tie, the network density effect is significant for values of density up to 0.60 . At individual ties greater than two, the effect of network density on exploration is significant for values up to 0.80 . Furthermore, this range includes the majority of observations (the means of network density is 0.20 and its standard deviation is 0.25 ). In summary, the analysis of the marginal effects of network density and individual ties provides support for Hypothesis 2. External network structure does have a significant effect on exploration in large professional service firms and its effect is greatest for sparse networks that include individual ties. 
Insert Table 4 and Figure 2 about here

\section{Robustness checks}

To ensure that the results are robust to alternative specifications, we also ran ordinary least squares regression and ordered probit analyses. The pattern and significance of results were consistent across the models. The results for the main explanatory variables also are unchanged in the reduced form model in Model 4. To ensure that our findings regarding the effect of individual ties were not an artifact of our coding method, we recoded the measures such that ratings of five only were counted as individual ties. The results are consistent with our main analysis, and the model fit did not differ significantly between the models. Using the average rating across ties rather than categorizing each tie as individual tie (v. firm or mixed) also shows a positive association between the investment of individual resources in relationships and exploration. Adding controls for the counts of firm ties and mixed ties also does not alter the pattern of results. Lastly, we also tested for curvilinear effects of individual ties and network density but did not find any evidence of these effects.

Given that the choice of which resources to invest in relationships was not randomly assigned, it is possible that an unobserved characteristic of the partners could drive both the way they build their relationships and their exploration performance. To address this endogeneity concern, we estimated two-stage least squares (2SLS) model using two instrumental variables, one for each of the explanatory network variables: the individualism-collectivism index of the partner's country (Hofstede, Hofstede \& Minkov, 2010) and the partner's gender. Both of these measures are reasonable instruments in that they are likely to be correlated with the partners networking behaviors but not with the error term. Unfortunately the F-statistics indicated that they were weak instruments. Because weak instruments lead to biases greater than the 
endogeneity they are meant to correct (Murray, 2006), we could not implement the instrumental variables regression; and consequently we could not completely rule out endogeneity in our study. We discuss the implications for our conclusions in the limitations section below.

\section{Discussion and conclusions}

By examining the implications of the resources invested in professional relationships for exploration in large firms, this study provides insight into an understudied area in strategy and organizations research - the role of network content for performance. We found support for our main argument that managers who invest primarily individual resources in their professional relationships perform better in terms of new business and new knowledge growth. Three different mechanisms could explain this result. As we have argued, managers who invest primarily individual resources in their professional relationships are exposed to a greater diversity of information, they have greater autonomy vis a vis the firm, and their contacts are more willing to provide resources in return. Consequently these managers should be better able to explore for new opportunities for the firm. One might be concerned that this finding is a result of quality differences in the individual resources or skills held by managers. Nevertheless, controls for human capital differences such as education and experience rule this out. We also included controls for other relationship characteristics such as tie strength to allay concerns that the closeness of the relationships rather than the choice to invest individual resources explained the relationship between individual ties and exploration. Furthermore, the positive relationship persists even controlling for the effects of network density, confirming that network content has an effect over and above that of network structure.

Our investigation also addresses a puzzle regarding the effect of network density on outcomes such as exploration and innovation in professional service firms. Although network 
scholars have long argued that dense networks hamper exploration and sparse networks support it, researchers studying professional service firms have argued that sparse networks are insufficient for exploration in this context due to the necessary involvement of clients in the generation of new knowledge and business (Fosstenløkken et al., 2003; Nikolova, 2012). Our analysis shows that network density (sparseness) does have a significant effect on exploration, but only when the network includes individual ties and is below average density. The lack of consistent support for the interaction effect for the full range of network density could reflect competing effects of density on performance. For example, Phelps (2010) finds that the technological diversity of a firm's alliance network increases its exploratory innovation and that this effect increases with the density of the network. Similarly, Mors (2010) suggests that density in the network facilitates integration of diverse information in manager networks. Future research could disentangle these competing effects of the interaction of density and diversity on exploration.

Recognition that managers invest not only firm resources but also individual resources in the relationships they build in their networks adds additional explanatory insight to the findings of previous studies of relationships in professional service firms. For example, as described by Briscoe and Tsai (2011) in their study of post-merger client relationship sharing in law firms, client sharing varied widely across partners. The findings from our study suggest that the extent to which the client relationships were based on individual ties or firm ties could be part of the explanation for differences in partner's willingness to share their clients with other lawyers. An important implication of our study is that firms may affect the behavior of managers by encouraging (or mandating) the use of firm resources when building and maintaining professional relationships - an approach that is clearly rational given the risk firms face of losing 
valuable relationships when managers leave the firm (Broschak, 2004; Rogan, 2014). This emphasis on the use of firm resources rather than individual resources is consistent with prior studies investigating the tension between individual and collective action that characterizes professional service firms (Alvesson \& Karreman, 2006; Anand et al., 2007; Briscoe, 2007; Morris, 2001). Yet, our results indicate that mandating the use of firm resources when building relationships may be problematic if it comes at the cost of reduced long-term performance. Maister (1985: 13) in describing the emphasis on firm control by several professional service firms ("i.e., the one-firm firm" culture) including Goldman Sachs, McKinsey and Latham \& Watkins warned that a "potential weakness of the one-firm firm culture is that it runs the danger of being insufficiently entrepreneurial." Similarly, research in sociology outside of the professional service firm context has also shown that a degree of individual malfeasance whereby individual members of the firm build networks to pursue their own entrepreneurial interests can actually benefit the firm as it may lead to new networks that subsequently support the growth of the firm (Erikson \& Bearman, 2006).

\section{Limitations}

This study represents a first attempt to investigate the resources invested in professional relationships and thus has limitations. We were interested in the challenge of exploration for large, established firms, and we therefore tested our hypotheses using data from a very large professional service firm. The focus on a single firm and a large firm naturally limits the generalizability of our findings. In very small firms where a distinction between the networks of individual managers and the networks of the firm does not exist (i.e. at the extreme, a onemember firm), our arguments would be less relevant. Thus, a boundary condition of our theory is that a divergence must exist between networks of the firm and the networks of its members. 
However, given the pervasiveness of the exploration challenge and the dominance of large professional service firms (e.g., The Big Four), we expect that our arguments and findings are relevant to a large portion of economic activity in professional services.

The main services provided by the firm we studied involved well-established methodologies and procedures but with a high degree of client contact, i.e., a "Nurse" according to Maister's (2004) consulting firm framework. It is therefore possible that our results would not generalize to firms that offer highly customized solutions or firms that have low client contact. Thus, further study of the role of individual ties in these firms is needed.

Lastly, negotiating access to the partners of the firm for the network data collection was difficult and therefore, our network data, like data in many exploratory network studies, are cross-sectional (e.g., Borgatti \& Cross, 2003; Chua et al., 2008; Mehra, Kilduff \& Brass, 2001; Rodan \& Galunic, 2004; Sosa, 2011; Vissa \& Chacar, 2009). While our data are fine-grained and our understanding of the context is well developed, the lack of longitudinal data limits the conclusions we can draw. We attempted to reduce the endogeneity concern, as in other network studies, but a potential for bias still remains. An important task for future research is the identification of exogenous shocks or stronger instruments to better address endogeneity concerns. Nevertheless, the finding that there is a significant positive relationship between ties developed by investing individual resources and managerial exploration is interesting, particularly because it highlights the idea that managers have different resources they can use to develop their professional relationships, and that this choice is significantly related to certain performance outcomes. Although we were careful not to make strong causality claims, our qualitative evidence is consistent with the direction of causality we propose. The ties we examine have lasted on average 3.6 years and up to 23.3 years, which indicates that the partners rely on 
ties that existed prior to the performance outcomes.

Despite these limitations, we believe that the relationship among these constructs will stimulate further research into the investment of resources in network ties. Future research in this area could further enhance our understanding of how managers' networks - and in particular the network content - affect performance. Because our aim was to introduce the novel construct of individual versus firm resources we took a static approach. A natural next step is the development of a dynamic perspective on the investment of resources in relationships. By investigating the process through which firm ties transition to individual ties and individual ties transition to firm ties, scholars can more fully develop theory for the investment of resources in relationships and related performance outcomes. Furthermore, we focused on one performance outcome, manager's exploration behavior. Future research into the investment of individual resources in relationships could further develop our understanding of the importance of individual ties for performance in professional service firms by examining other outcomes such as ambidexterity (Fu, Flood \& Morris, 2016; Raisch \& Birkinshaw, 2008) or the career mobility of managers (Mawdsley \& Somaya, 2016).

\section{Theoretical contributions}

In closing, our study offers three main theoretical contributions. First, our arguments help to address the contradictory arguments regarding the effect of external networks on exploration between the network literature and the professional service firms' literature. Because exploration in professional services requires the involvement of clients, sparse networks alone are insufficient to support exploration activities. As we argue and show, the relationship of sparse networks to exploration is conditional upon having individual ties in the network. Our study therefore highlights an important nuance to the role of networks for exploration in professional 
service firms and extends research into the important role of personalized interactions for the growth and survival of these firms (Kijkuit \& van den Ende, 2010; Taminiau \& Berghman, 2010).

Second, our study extends prior network research by examining a previously overlooked aspect of network content - the investment of resources in relationships. As such our study answers the call for more research into network content (Brass et al., 2004; Hoang \& Antoncic, 2003; Ibarra et al., 2005). In particular, we argue and show that the types of resources invested in relationships have an effect on exploration over and above network structure. This finding relates to recent research in the sociology of networks by Aral and Van Alstyne (2011), which proposes that trade-offs exist between network diversity and the bandwidth of the ties in the network, i.e. their ability to transmit information and resources. Hence, considering structure in absence of the content that flows in the tie or content in the absence of structure risks overlooking nuances in their effects. Future studies on networks may therefore benefit from examining the resources that managers invest in building and maintaining relationships.

Lastly, our findings have implications for the literature on exploration in established firms (e.g. Ahuja \& Lampert, 2001; Burgelman, 1983; Kacperczyk, 2012). Our study offers an alternative means to counter firms' tendencies towards exploitation. As prior research has shown, this tendency must be studied not only at the firm level, but also at the individual level (Criscuolo et al., 2013; Dobrev \& Barnett, 2005; Groysberg \& Lee, 2009). We show here that managers' investments of individual resources when building relationships can help overcome this exploitation tendency. Allowing managers to build individual ties may seem counterintuitive given the lower control the firm has over these relationships. However, considered in terms of long-term performance, doing so may actually benefit the firm. 


\section{References}

Ahuja, G. (2000). Collaboration networks, structural holes, and innovation: A longitudinal study. Administrative Science Quarterly, 45, 425-455.

Ahuja, G., Lampert, M.C. (2001). Entrepreneurship in the large corporation: A longitudinal study of how established firms create breakthrough inventions. Strategic Management Journal, 22(6- 7), 521-543.

Ai, C., Norton, E. C. (2003). Interaction terms in logit and probit models. Economics letters, 80(1), 123-129.

Aiken, L.S., West, S.G. (1991). Multiple Regression: Testing and Interpreting Interactions. London, UK: Sage Publications.

Alvesson, M., Karreman, D. (2006). Professional service firms as collectivities: A cultural and processual view. In Greenwood, R., Suddaby, R. (Eds). Professional Service Firms. Paris, France: JAI Press.

Anand, N., Gardner, H.K., Morris, T. (2007). Knowledge-based innovation: Emergence and embedding of new practice areas in management consulting firms. Academy of Management Journal, 50(2), 406-428.

Aral, S., \& Van Alstyne, M. (2011). The diversity-bandwidth trade-off. American Journal of Sociology, 117(1), 90-171.

Blau, P. (1964). Exchange and Power in Social Life. New York: Wiley.

Borgatti, S.P., Everett, M.G., Freeman, L.C. (2002). UCINET for Windows: Software for Social Network Analysis. Harvard: Analytic Technologies.

Borgatti, S.P., Cross, R. (2003). A relational view of information seeking and learning in social networks. Management Science, 49(4), 432-445.

Borgatti, S.P., Foster, P. C. (2003). The network paradigm in organizational research: A review and typology. Journal of Management, 29, 991-1013.

Borgatti, S. P., Halgin, D. S. (2011). On network theory. Organization Science, 22(5), 11681181.

Bouty, I. (2000). Interpersonal and interaction influences on informal resource exchanges between R\&D researchers across organizational boundaries. Academy of Management Journal, 43(1), 50-65.

Brass, D., Galaskiewicz, J., Greve, H., Tsai, W. (2004). Taking stock of networks and organizations: A multilevel perspective. Academy of Management Journal, 47(6), 795-817.

Briscoe, F. (2007). From iron cage to iron shield? How bureaucracy enables temporal flexibility for professional service workers. Organization Science, 18(2), 297-314.

Briscoe, F., Tsai, W. (2011). Overcoming relational inertia: How organizational members respond to acquisition events in a law firm. Administrative Science Quarterly, 56(3), 408-440.

Brivot, M. (2011). Controls of knowledge production, sharing and use in bureaucratized professional service firms. Organization Studies, 32(4), 489-508. 
Broschak, J.P. (2004). Manager mobility and market interface: The effect of managers' career mobility on the dissolution of market ties. Administrative Science Quarterly, 49(4), 608-640.

Burgelman, R.A. (1983). A process model of internal corporate venturing in the diversified major firm. Administrative Science Quarterly, 28(2), 223-244.

Burgelman, R.A. (1991). Intraorganizational ecology of strategy making and organizational adaptation: theory and field research. Organization Science, 2(3), 239-262.

Burt, R.S. (1984). Network items and the general social survey. Social Networks, 6, 293-339.

Burt, R.S. (1992). Structural Holes. Cambridge, MA: Harvard University Press.

Burt, R.S. (2000). The network structure of social capital. Research in Organizational Behavior, $22,345-423$.

Burt, R.S. (2007). Second-hand brokerage: Evidence on the importance of local structure for managers, bankers, and analysts. Academy of Management Journal, 50, 119-158.

Capaldo, A. (2007). Network structure and innovation: The leveraging of a dual network as a distinctive relational capability. Strategic Management Journal, 28, 585-608.

Christensen, C. \& Raynor, M. (2003). The Innovator's Solution: Creating and sustaining successful growth. Harvard University Press: Cambridge, MA.

Chua, R.Y.J., Ingram, P., Morris, M.W. (2008). From the head and the heart: Locating cognitionand affect-based trust in managers' professional networks. Academy of Management Journal, 51(3), 436-452.

Criscuolo, P., Salter, A., Ter Wal, A.L. (2013). Going underground: bootlegging and individual innovative performance. Organization Science, 25(5), 1287-1305.

Cross, R., Cummings, J.N. (2004). Tie and network correlates of individual performance in knowledge-intensive work. Academy of Management Journal, 47(6), 928-937.

Dobrev, S.D., Barnett, W.P. (2005). Organizational roles and transition to entrepreneurship. Academy of Management Journal, 48(3), 433-449.

Emerson, R.M. (1962). Power-dependence relations. American Sociological Review, 27, 31-41.

Erikson, E., Bearman, P. (2006). Malfeasance and the foundations for global trade: The structure of English trade in the East Indies, 1601-1833. American Journal of Sociology, 112(1), 195-230.

Everett, M.G., Borgatti, S.P. (2005). Ego network betweenness. Social Networks, 27(1), 31-38.

Fosstenløkken, S. M., Løwendahl, B. R., Revang, Ø. (2003). Knowledge development through client interaction: A comparative study. Organization Studies, 24(6), 859-879.

Freeman, S., Sandwell, M. (2008). Professional service firms entering emerging markets: The role of network relationships. Journal of Services Marketing, 22(3), 198-212.

$\mathrm{Fu}$, N. (2015). The role of relational resources in the knowledge management capability and innovation of professional services firms. Human Relations, 68(5), 731-764.

Fu, N., Flood, P.C., Morris, T. (2016). Organizational ambidexterity and professional firm performance: The moderating role of organizational capital. Journal of Professions and Organizations, Advance Access, 1-16. 
Galaskiewicz, J. (1985). Interorganizational relations. Annual Review of Sociology, 11, 281-304.

Gardner, H. K., Anand, N., Morris, T. (2008). Chartering new territory: Diversification, legitimacy, and practice area creation in professional service firms. Journal of Organizational Behavior, 29(8), 1101-1121.

Glückler, J., Armbrüster, T. (2003). Bridging uncertainty in management consulting: The mechanisms of trust and networked reputation. Organization Studies, 24(2), 269-297.

Gouldner, A.W. (1960). The norm of reciprocity: A preliminary statement. American Sociological Review, 25(2), 161-178.

Granovetter, M. (1973). The strength of weak ties. American Journal of Sociology, 78, 13601380 .

Greene, W. (2010). Testing hypotheses about interaction terms in nonlinear models. Economics Letters, 107(2), 291-296.

Groysberg, B., Lee, L. (2009). Hiring stars and their colleagues: Exploration and exploitation in professional service firms. Organization Science, 20(4), 740-758.

Gulati, R., Nohria, N., Zaheer, A. (2000). Strategic networks. Strategic Management Journal, Special issue, 21(3), 203-215.

Hansen, M.T. (1999). The search-transfer problem: The role of weak ties in sharing knowledge across organization subunits. Administrative Science Quarterly, 44, 82-111.

Hansen, M.T., Nohria, N., Tierney, T. (1999). What's your strategy for managing knowledge? Harvard Business Review, March-April.

Hansen, M.T., Mors, M.L., Løvås, B. (2005). Knowledge sharing in organizations: Multiple networks, multiple phases. Academy of Management Journal, 48, 776-793.

Hoang, H., Antoncic, B. (2003). Network-based research in entrepreneurship: A critical review. Journal of Business Venturing, 18, 165-187.

Hoetker, G. (2007). The use of logit and probit models in strategic management research: Critical issues. Strategic Management Journal, 28(4), 331-343.

Hofstede, G., Hofstede, G.J., Minkov, M. (2010). Cultures and Organizations: Software of the Mind. 3rd Edition, New York: McGraw-Hill.

Ibarra, H., Kilduff, M., Tsai, W. (2005). Zooming in and out: Connecting individuals and collectivities at the frontiers of organizational network research. Organization Science, 16(4), 359-71.

Kacperczyk, A.J. (2012). Opportunity structures in established firms: Entrepreneurship versus intrapreneurship in mutual funds. Administrative Science Quarterly, 57(3), 484-521.

Karantinou, K. M., Hogg, M. K. (2009). An empirical investigation of relationship development in professional business services. Journal of Services Marketing, 23(4), 249-260.

Katila, R., Ahuja, G. (2002). Something old, something new: A longitudinal study of search behavior and new product introduction. Academy of Management Journal, 45(6), 1183-1194.

Kennedy, P. (2003). A Guide to Econometrics. $5^{\text {th }}$ Edition. Cambridge, MA: MIT Press. 
Kijkuit, B., van den Ende, J. (2010). With a little help from our colleagues: A longitudinal study of social networks for innovation. Organization Studies, 31(4), 451-479.

Lazer, D. and Friedman, A., (2007). The network structure of exploration and exploitation. Administrative Science Quarterly, 52(4), pp.667-694.

Levene, H. (1960). Robust tests for equality of variances. In Olkin, I. (Ed). Contributions to Probability and Statistics. Stanford, CA: Stanford University Press.

Lin, N. (2001). Social Capital: A Theory of Social Structure and Action. Cambridge, UK: Cambridge University Press.

Litwak, E. (1961). Models of bureaucracy which permit conflict. American Journal of Sociology, 67, 177-184.

Long, J.S. (1997). Regression Models for Categorical and Limited Dependent Variables. Thousand Oaks, CA: SAGE Publications.

Løwendahl, B.R. (1997). Strategic Management of Professional Service Firms. Copenhagen Business School Press.

Løwendahl, B.R. (2005). Strategic Management of Professional Service Firms, $3^{\text {rd }}$ Edition. Copenhagen Business School Press.

Maister, D. (1985). The one-firm firm. Sloan Management Review, 27(1), 3-13.

Maister, D. (1993). Managing the Professional Service Firm. New York, NY: Simon \& Schuster.

Maister, D. (2004). The anatomy of a consulting firm. In Fombrun, C .J. and Nevis, M. D. (Eds.). Essential Tools for Managing Consulting. Pearson Prentice Hall, Upper Saddle River, NJ.

March, J. G. (1991). Exploration and exploitation in organizational learning. Organization Science, 2, 71-87.

Mariotti, F., Delbridge, R. (2012). Overcoming network overload and redundancy in interorganizational networks: The roles of potential and latent ties. Organization Science, 23(2), 511-528.

Marsden, P. (2002). Egocentric and sociocentric measures of network centrality. Social Networks, 24(4), 407-422.

Marsden, P., Campbell, K. (1984). Measuring tie strength. Social Forces, 63, 482-501.

Mawdsley, J. K., Somaya, D. (2016). Employee mobility and organizational outcomes: An integrative conceptual framework and research agenda. Journal of Management, 42(1), 85-113.

McGrath, R.G. (2001). Exploratory learning, innovative capacity and managerial oversight. Academy of Management Journal, 44(1), 118-131.

Mehra, A., Kilduff, M., Brass, D.J. (2001). The social networks of high and low self-monitors: Implications for workplace performance. Administrative Science Quarterly, 35,121-46.

Mom, T. J. M., van Neerijnen, P., Reinmoeller, P., Verwaal, E. (2015.) Relational capital and individual exploration: Unravelling the influence of goal alignment and knowledge acquisition. Organization Studies, 36(6), 809-829. 
Moran, P. (2005). Structural vs. relational embeddedness: Social capital and managerial performance. Strategic Management Journal, 26(12), 1129-1151.

Morris, T. (2001). Asserting property rights: Knowledge codification in the professional service firm. Human Relations, 54, 819-838.

Mors, M.L. (2010). Innovation in a global consulting firm: When the problem is too much diversity. Strategic Management Journal, 31(8), 841-872.

Murray M.P. (2006) Avoiding invalid instruments and coping with weak instruments. The Journal of Economic Perspectives. 20(4): 111-132.

Nahapiet, J., Ghoshal, S. (1998). Social capital, intellectual capital, and the organizational advantage. Academy of Management Review, 23(2), 242-266.

Nikilova, N. (2012). Innovating through clients. pp. 86-106. Handbook of Research on Entrepreneurship in Professional Services. Cheltenham: Edward Elgar

Obstfeld, D. (2005). Social networks, the tertius iungens orientation, and involvement in innovation. Administrative Science Quarterly, 50, 100-130.

Penrose, E. (1959). The Theory of the Growth of the Firm. Oxford, UK: Oxford University Press. Phelps, C. (2010). A longitudinal study of the influence of alliance network structure and composition on firm exploratory innovation. Academy of Management Journal, 53(4), 890-913.

Podolny, J.M. (2001). Networks as the pipes and prisms of the market. American Journal of Sociology, 107, 33-60.

Podolny, J.M., Baron, J.N. (1997). Resources and relationships: Social networks and mobility in the workplace. American Sociology Review, 62(5), 673-693.

Raisch, S., Birkinshaw, J. (2008). Organizational ambidexterity: Antecedents, outcomes, and moderators. Journal of Management, 34(3), 375-409.

Reagans, R., McEvily, B. (2003). Network structure and knowledge transfer: The effects of cohesion and range. Administrative Science Quarterly, 48, 240-267.

Reagans, R., Zuckerman, E. (2001). Networks, diversity, and productivity: The social capital of corporate R\&D teams. Organization Science, 12, 502-517.

Reihlen, M. \& Werr, A. (2012) Towards a multi-level approach to studying entrepreneurship in professional services. pp. 3-22. Handbook of Research on Entrepreneurship in Professional Services. Cheltenham: Edward Elgar.

Reihlen, M. \& Werr, A. (2015) Entrepreneurship and professional service firms. pp. 255-278. In L. Empson, D. Muzio, J.P. Broschak, B. Hinings (Eds.) The Oxford Handbook of Professional Service Firms. Oxford: Oxford University Press.

Robertson, M., Scarbrough, H., Swan, J. (2003). Knowledge creation in professional service firms: Institutional effects. Organization Studies, 24(6), 831-857.

Rodan, S., Galunic, C.D. (2004). More than network structure: How knowledge heterogeneity influences managerial performance and innovativeness. Strategic Management Journal, 25(6), 541-562. 
Rogan, M. (2014). Too close for comfort. The effect of embeddedness and competitive overlap on client relationship retention following an acquisition. Organization Science, 25(1), 185-203.

Skjølsvik T., Løwendahl B.R., Kvålshaugen R., Fosstenløkken, S.M. (2007) Choosing to Learn and Learning to Choose: Strategies for client co-production and knowledge development. California Management Review 49(3): 110-128.

Soda, G., Zaheer, A. (2008). The evolution of network structure: Where do structural holes come from? Administrative Science Quarterly, 54(1), 1-31.

Sorensen, J.B. (2007). Bureaucracy and entrepreneurship: Workplace effects on entrepreneurial entry. Administrative Science Quarterly, 52(3), 387-412.

Sorenson, O. Rogan, M. (2014). (When) do organizations have social capital? Annual Review of Sociology, 40, 261-280.

Sosa, M.E. (2011). Where do creative interactions come from? The role of tie content and social networks. Organization Science, 22(1), 1-21.

Sparrowe, R.T., Liden, R. C., Wayne S. J., Kraimer, M. L. (2001). Social networks and the performance of individuals and groups. Organization Studies, 44(2), 316-325.

Taminiau, Y., Berghman, L. (2010). Let's go to lunch!: Informal client contacts by consultants in the UK. International Journal of Management Concepts and Philosophy. 4(2), 194-211.

Tasselli, S. (2015). Social networks and inter-professional knowledge transfer: The case of healthcare professionals. Organization Studies, 36(7), 841-872.

Tichy, N.M., Tushman, M.L., Fombrun, C. (1979). Social network analysis for organization. Academy of Management Review, 4, 507-19.

Tortoriello, M., Krackhardt, D. (2010). Activating cross-boundary knowledge: The role of simmelian ties in the generation of innovations. Academy of Management Journal, 53(1), 167181.

Tsai, W., Ghoshal, S. (1998). Social capital and value creation: The role of intrafirm networks. Academy of Management Journal, 43, 464-476.

Uzzi, B. (1999). Embeddedness in the making of financial capital: How social relations and networks benefit firms. American Sociological Review, 64(4), 481-506.

Vissa, B., Bhagavatula, S. (2012). The causes and consequences of churn in entrepreneurs' personal networks. Strategic Entrepreneurship Journal, 6, 273-289.

Vissa, B., Chacar, A. (2009). Leveraging ties: The contingent value of entrepreneurial advice networks on Indian software venture performance. Strategic Management Journal, 30(11), 11791191.

Werr, A., Stjernberg, T. (2003). Exploring management consulting firms as knowledge systems. Organization Studies, 24(6), 881-908.

White, P.E. (1974). Resources as determinants of organizational behavior. Administrative Science Quarterly, 19(3), 366-379.

Wiersema, M. F., Bowen, H. P. (2009). The use of limited dependent variable techniques in strategy research: issues and methods. Strategic Management Journal, 30(6), 679-692. 
Table 1. Descriptive data and correlations ${ }^{\mathrm{a}}$.

\begin{tabular}{|c|c|c|c|c|c|c|c|c|c|c|c|c|c|c|c|c|}
\hline & Variable & Mean & s.d. & 1 & 2 & 3 & 4 & 5 & 6 & 7 & 8 & 9 & 10 & 11 & 12 & 13 \\
\hline 1. & Exploration & 2.98 & 0.81 & & & & & & & & & & & & & \\
\hline 2. & Age & 43.61 & 4.45 & -.08 & & & & & & & & & & & & \\
\hline 3. & Education level & 3.71 & 0.56 & .13 & .21 & & & & & & & & & & & \\
\hline 4. & Gender (female) & 0.06 & 0.25 & -.07 & .04 & -.05 & & & & & & & & & & \\
\hline 5. & Time to partner & 9.56 & 3.61 & -.28 & -.32 & -.30 & .06 & & & & & & & & & \\
\hline 6. & Revenue generation capability & 3.47 & 1.03 & .19 & -.11 & .14 & .03 & -.01 & & & & & & & & \\
\hline 7. & Industry average growth rate & 0.07 & 0.03 & .24 & -.04 & .18 & .03 & -.08 & .07 & & & & & & & \\
\hline 8. & Count of industries in network & 1.16 & 0.69 & .16 & -.01 & .22 & .02 & -.09 & -.09 & .19 & & & & & & \\
\hline 9. & Average tie strength & 3.44 & 0.77 & .05 & .11 & .24 & .17 & -.12 & -.06 & .10 & .04 & & & & & \\
\hline 10. & External network size & 4.74 & 2.43 & -.02 & .16 & .20 & .01 & .13 & .08 & -.00 & .28 & .10 & & & & \\
\hline 11. & Internal network size & 11.57 & 3.48 & .01 & -.05 & -.21 & -.07 & -.04 & -.15 & -.12 & -.14 & -.14 & -.30 & & & \\
\hline 12. & Internal network density & 0.28 & 0.16 & .06 & .15 & .19 & .13 & .05 & .00 & .23 & .03 & .25 & .17 & -.31 & & \\
\hline 13. & Individual ties (count) & 1.43 & 1.56 & .14 & .09 & .19 & .23 & .05 & .03 & .04 & .26 & .39 & .48 & -.15 & .05 & \\
\hline 14. & External network density & 0.20 & 0.25 & -.12 & -.04 & .01 & .00 & .09 & .08 & .06 & -.04 & .16 & -.05 & .05 & .09 & .02 \\
\hline
\end{tabular}

${ }^{\mathrm{a}} \mathrm{N}=77$ 
Table 2. Ordered logistic regression of managerial exploration ${ }^{\mathrm{a}}$.

\begin{tabular}{|c|c|c|c|c|}
\hline & Model 1 & Model 2 & Model 3 & Model 4 \\
\hline Age & $\begin{array}{l}-0.095 \\
(0.066)\end{array}$ & $\begin{array}{l}-0.113+ \\
(0.065)\end{array}$ & $\begin{array}{l}-0.111+ \\
(0.067)\end{array}$ & \\
\hline Education level & $\begin{array}{l}0.174 \\
(0.608)\end{array}$ & $\begin{array}{l}0.183 \\
(0.580)\end{array}$ & $\begin{array}{l}0.194 \\
(0.576)\end{array}$ & \\
\hline Gender (female) & $\begin{array}{l}-0.627 \\
(1.391)\end{array}$ & $\begin{array}{l}-0.812 \\
(1.821)\end{array}$ & $\begin{array}{l}-0.790 \\
(1.812)\end{array}$ & \\
\hline Time to partner & $\begin{array}{l}-0.227 * * * \\
(0.059)\end{array}$ & $\begin{array}{l}-0.264 * * * \\
(0.067)\end{array}$ & $\begin{array}{l}-0.268 * * * \\
(0.070)\end{array}$ & $\begin{array}{l}-0.214 * * * \\
(0.043)\end{array}$ \\
\hline Revenue generation capability & $\begin{array}{l}0.277 \\
(0.273)\end{array}$ & $\begin{array}{l}0.293 \\
(0.284)\end{array}$ & $\begin{array}{l}0.290 \\
(0.289)\end{array}$ & \\
\hline Industry average growth rate & $\begin{array}{l}9.810+ \\
(5.560)\end{array}$ & $\begin{array}{l}9.596+ \\
(5.643)\end{array}$ & $\begin{array}{l}8.778 \\
(5.835)\end{array}$ & \\
\hline Count of industries in network & $\begin{array}{l}0.405 \\
(0.593)\end{array}$ & $\begin{array}{l}0.380 \\
(0.590)\end{array}$ & $\begin{array}{l}0.410 \\
(0.574)\end{array}$ & \\
\hline Average tie strength & $\begin{array}{l}0.156 \\
(0.471)\end{array}$ & $\begin{array}{l}-0.334 \\
(0.493)\end{array}$ & $\begin{array}{l}-0.335 \\
(0.489)\end{array}$ & \\
\hline External network size & $\begin{array}{l}-0.083 \\
(0.086)\end{array}$ & $\begin{array}{l}-0.202 * \\
(0.102)\end{array}$ & $\begin{array}{l}-0.216^{*} \\
(0.098)\end{array}$ & $\begin{array}{l}-0.172+ \\
(0.093)\end{array}$ \\
\hline Internal network size & $\begin{array}{l}0.041 \\
(0.089)\end{array}$ & $\begin{array}{l}0.040 \\
(0.086)\end{array}$ & $\begin{array}{l}0.045 \\
(0.086)\end{array}$ & \\
\hline Internal network density & $\begin{array}{l}0.078 \\
(2.030)\end{array}$ & $\begin{array}{l}0.353 \\
(2.027)\end{array}$ & $\begin{array}{l}0.429 \\
(2.198)\end{array}$ & \\
\hline External network density & $\begin{array}{l}-0.612 \\
(1.260)\end{array}$ & $\begin{array}{l}-0.845 \\
(1.247)\end{array}$ & $\begin{array}{l}-0.981 \\
(0.977)\end{array}$ & $\begin{array}{l}-0.784 \\
(0.850)\end{array}$ \\
\hline Individual ties & & $\begin{array}{l}0.416 * * \\
(0.136)\end{array}$ & $\begin{array}{l}0.414 * * \\
(0.140)\end{array}$ & $\begin{array}{l}0.282 * \\
(0.131)\end{array}$ \\
\hline $\begin{array}{l}\text { Individual ties } \\
\quad * \text { Ext. network density }\end{array}$ & & & $\begin{array}{l}-0.372 \\
(1.228)\end{array}$ & $\begin{array}{l}-0.522 \\
(1.134)\end{array}$ \\
\hline $\begin{array}{l}\text { Log Pseudo-likelihood } \\
\text { Change in d.f. } \\
-2\left(L_{L}-L_{2} L_{2}\right)^{b}\end{array}$ & $\begin{array}{l}-142.84 \\
-\end{array}$ & $\begin{array}{l}-139.96 \\
2 \\
5.76^{+}\end{array}$ & $\begin{array}{l}-139.87 \\
1 \\
0.18\end{array}$ & -145.53 \\
\hline
\end{tabular}

${ }^{a} \mathrm{~N}=77$; Robust standard errors clustered by performance rater in parentheses; Cut points not reported; Three skill area dummies (four categories, one omitted) included but not reported in all models. Model 4 is a reduced form model retaining only significant control variables.

${ }^{\mathrm{b}}$ For likelihood ratio tests, comparison is with previous model by dependent variable.

$$
\begin{gathered}
+\mathrm{p}<0.10 \\
* \mathrm{p}<0.05 \\
* * \mathrm{p}<0.01 \\
* * * \mathrm{p}<0.001
\end{gathered}
$$


Table 3. Marginal effect of individual ties on managerial exploration ${ }^{\mathrm{a}}$.

\begin{tabular}{lll}
\hline Individual & \multicolumn{2}{c}{ Exploration } \\
ties & $25^{\text {th }}$ percentile & $75^{\text {th }}$ percentile \\
\hline \multirow{2}{*}{1} & $0.114^{* *}$ & $0.217^{* * *}$ \\
& $(0.037)$ & $(0.054)$ \\
2 & $0.088^{* *}$ & $0.274 * * *$ \\
& $(0.031)$ & $(0.057)$ \\
3 & $0.065^{*}$ & $0.327^{* * *}$ \\
& $(0.027)$ & $(0.065)$ \\
4 & $0.047^{*}$ & $0.365^{* * *}$ \\
& $(0.023)$ & $(0.073)$ \\
5 & $0.032+$ & $0.380^{* * *}$ \\
& $(0.020)$ & $(0.077)$ \\
\hline
\end{tabular}

${ }^{a}$ Marginal effects calculated using the estimates from Model 2 of Table 2. All covariates except individual ties at sample mean.

$$
\begin{gathered}
+\mathrm{p}<0.10 \\
* \mathrm{p}<0.05 \\
* * \mathrm{p}<0.01 \\
* * * \mathrm{p}<0.001
\end{gathered}
$$


Table 4. Marginal effect of individual ties and network density on managerial exploration $\left(75^{\text {th }} \text { percentile }\right)^{\mathrm{a}}$.

\begin{tabular}{|c|c|c|c|c|}
\hline \multirow[b]{2}{*}{$\begin{array}{l}\text { Network } \\
\text { Density }\end{array}$} & \multicolumn{4}{|c|}{ Individual Ties } \\
\hline & 0 & 1 & 2 & 3 \\
\hline 0.0 & $\begin{array}{l}0.177 * * * \\
(0.040)\end{array}$ & $\begin{array}{l}0.242 * * * \\
(0.049)\end{array}$ & $\begin{array}{l}0.309 * * * \\
(0.067)\end{array}$ & $\begin{array}{l}0.360 * * * \\
(0.074)\end{array}$ \\
\hline 0.2 & $\begin{array}{l}0.166 * * \\
(0.058)\end{array}$ & $\begin{array}{l}0.219 * * * \\
(0.058)\end{array}$ & $\begin{array}{l}0.277 * * * \\
(0.061)\end{array}$ & $\begin{array}{l}0.330 * * * \\
(0.067)\end{array}$ \\
\hline 0.4 & $\begin{array}{l}0.155 \\
(0.100)\end{array}$ & $\begin{array}{l}0.197 * \\
(0.078)\end{array}$ & $\begin{array}{l}0.243 * * * \\
(0.064)\end{array}$ & $\begin{array}{l}0.290 * * * \\
(0.079)\end{array}$ \\
\hline 0.6 & $\begin{array}{l}0.144 \\
(0.141)\end{array}$ & $\begin{array}{l}0.176^{+} \\
(0.099)\end{array}$ & $\begin{array}{l}0.210 * * \\
(0.076)\end{array}$ & $\begin{array}{l}0.247^{*} \\
(0.116)\end{array}$ \\
\hline 0.8 & $\begin{array}{l}0.134 \\
(0.179)\end{array}$ & $\begin{array}{l}0.155 \\
(0.117)\end{array}$ & $\begin{array}{l}0.178^{*} \\
(0.091)\end{array}$ & $\begin{array}{l}0.203 \\
(0.156)\end{array}$ \\
\hline 1.0 & $\begin{array}{l}0.125 \\
(0.212)\end{array}$ & $\begin{array}{l}0.137 \\
(0.132)\end{array}$ & $\begin{array}{l}0.150 \\
(0.102)\end{array}$ & $\begin{array}{l}0.163 \\
(0.184)\end{array}$ \\
\hline
\end{tabular}

${ }^{a}$ Marginal effects calculated using the estimates from Model 3 of Table 2. All covariates except individual ties and network density are at sample mean.

$+\mathrm{p}<0.10$

$* \mathrm{p}<0.05$

$* * \mathrm{p}<0.01$

$* * * \mathrm{p}<0.001$ 
Figure 1. Marginal effect of individual ties on managerial exploration ${ }^{\mathrm{a}}$.

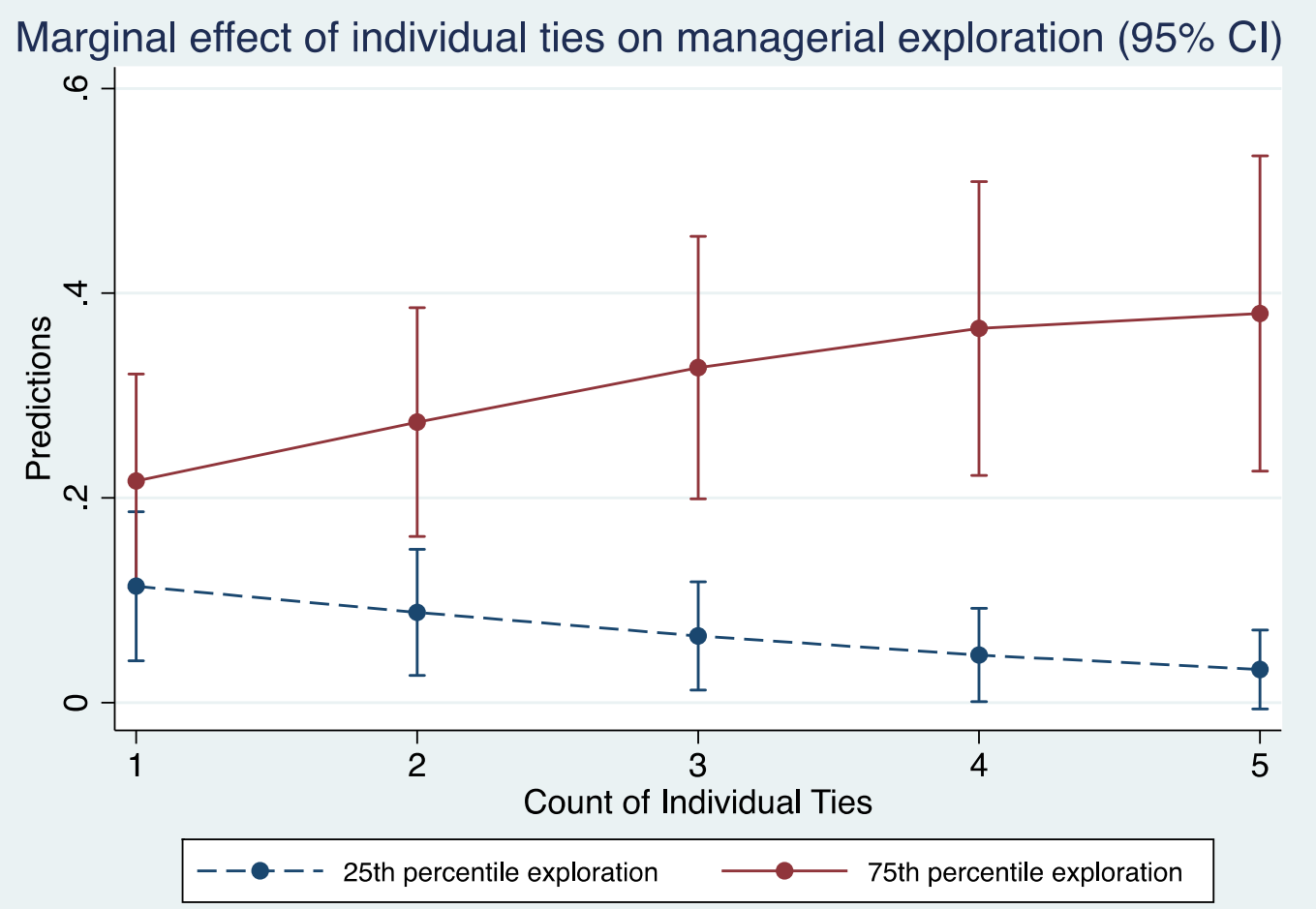

${ }^{\mathrm{a}}$ Graph based on marginal effects reported in Table 3. 
Figure 2. Marginal effect of individual ties and network density on managerial exploration $\left(75^{\text {th }} \text { percentile }\right)^{\mathrm{a}}$.

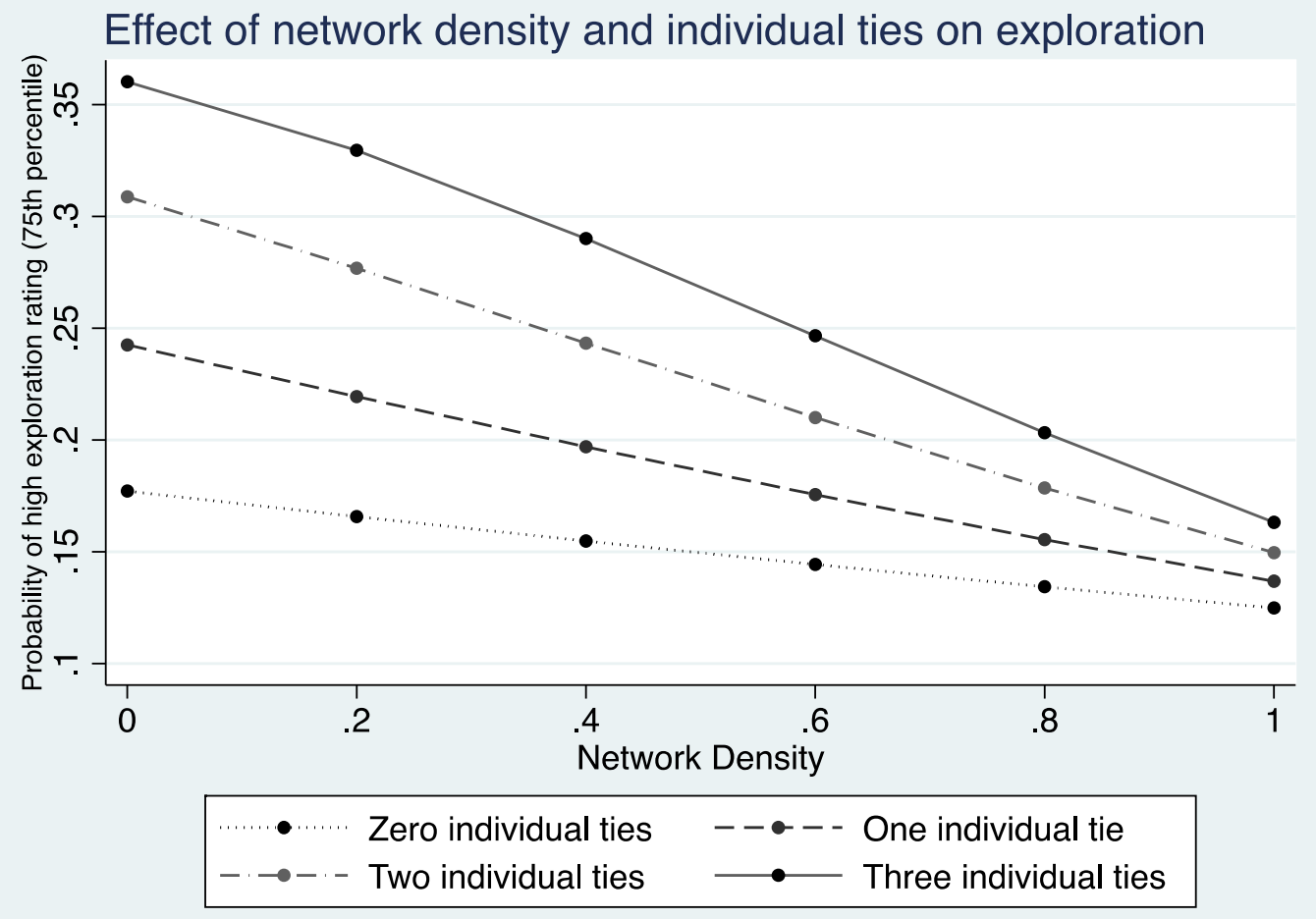

${ }^{\mathrm{a}}$ Graph based on estimates of marginal effects reported in Table 4. 


\section{Appendix. Name generator questions ${ }^{a}$.}

\begin{tabular}{ll}
\hline Network & Question \\
\hline $\begin{array}{l}\text { Identification network } \\
\text { Negotiation network }\end{array}$ & $\begin{array}{l}\text { Who are your most reliable sources of valuable information in } \\
\text { terms of identifying attractive business opportunities? } \\
\text { Who are your most valuable contacts in terms of gaining new } \\
\text { business (i.e. closing deals)? }\end{array}$ \\
$\begin{array}{l}\text { Knowledge network } \\
\text { Who do you consider your most important sources of valuable } \\
\text { knills development network }\end{array}$ & $\begin{array}{l}\text { On whom do you rely to help you develop skills and knowledge in } \\
\text { your area of expertise? }\end{array}$ \\
& $\begin{array}{l}\text { On whom do you rely to sponsor and support your projects and } \\
\text { activities? }\end{array}$ \\
&
\end{tabular}

external network. 